of interest and the far-flung activities of Bootham Old Boys. The headmaster read messages of greeting from the Minister of Education, Sir Michael Sadler and many others. Referring to distinguished former members such as Joseph Barcroft, F. W. Oliver, S. P. Thompson, J. Gilbert Baker, Lewis Richardson, Sir George Newman and Henry Seebohm, he claimed that the Society has performed, through the lives of its members, great services to the development of tropical countries, as well as to pure science. Above all, it has given to a great number of men a permanent enrichment of life. Mr. J. L. Paton, formerly High Master of Manchester Grammar School, gave an inspiring address. He warmly commended the pioneering step taken a hundred years ago in bringing biological science into the school. He spoke of these naturalists overseas as conquerors, not of men, but of Nature. Finally, he maintained that men do not really know Nature until they know her as the interpreter or the medium of the supernatural.

\section{The Diesel-Electric Train Ferry Scilla}

Fon nearly forty years a service of train ferries connecting Sicily with the mainland has been running across the Strait of Messina. The distance between the two terminal points, Messina and Villa San Giovanni, is about five miles. Until recently the service was maintained by two small ships which crossed in opposite directions simultaneously, so as to prevent an accumulation of rolling stock on either side of the Strait. In October 1931 they were replaced by the Diesel-electric train ferry Scilla, which has a displacement of 4,000 tons and a length of $358 \mathrm{ft}$. In Engineering of February 23, a full description is given of the vessel. It has a horse power of 5,000 and a maximum speed of 17 miles per hour. The coaches are embarked and disembarked at the end by means of a movable bridge. The adoption of Diesel-electric propulsion for a vessel of this type has several advantages, in particular its ability to run economically at different speeds, and rapid and accurate manœuvring. There are two steering stations on the vessel, one on the boat deck and the other in the engine-room, and interlocks are provided so that it is impossible to operate the controls from both stations at the same time. The ferry carries both passengers and goods, and traffic in the latter. and more particularly the transport of fruit, has steadily increased since its inauguration. It is of a seasonal nature with a winter maximum, a summer minimum and a short peak load in June. The crossing takes 25 minutes and there are first and second class restaurants on the passenger deck. The corridor deck contains first, second and third class saloons for the passengers.

\section{A James Watt Letter}

A moss interesting letter written by James Watt in 1784 to his father-in-law, Mr. Macgregor, has just been presented to the University of Glasgow by Mr. W. J. Wilson. The letter was published in full in the Glasgow Herald of February 9. Watt had once made surveys for the Caledonian Canal, and it had been proposed that he should become the engineer of the scheme. By 1784, however, he had become so fully occupied with the engine business at Birmingham that he felt he could not accept the position. $\mathrm{He}$ said, "the contriving of engines and the other necessary attention to a business which is now very extensive takes up all the time that bad health will permit me to work, and it is possible that, setting aside the damage which the distraction of my attention might do to the partnership, my share of the loss in the engine business might exceed my gain by the canal direction." Speaking of his great contemporary Arkwright, Watt said, "he is to say no worse one of the most self sufficient ignorant men $I$ have ever met with. Yet by all I can learn he is certainly a man of merit in his way and one to whom Britain is much indebted and whom she should honour and reward, for whoever invented spinning Arkwright certainly had the merit of performing the most difficult part, which was the making of it usefull." When Watt wrote this letter he was forty-eight years of age, and eight years previously had married his second wife, Anne Macgregor.

\section{Institution of Mechanical Engineers}

Ar the annual general meeting of the Institution of Mechanical Engineers held on February 16, the annual report was adopted and the ballot for the election of officers declared, Mr. C. Day becoming president for the ensuing year in succession to $\mathrm{Mr}$. A. E. L. Chorlton. Honorary life membership, it was announced, had been conferred upon Mr. L. St. L. Pendred and the Right Hon. Lord Invernairn. The report showed a net increase in the roll of member ship of 61 names, the total number of members now being 11,356. The total revenue of the Institution was $£ 34,074$. During the year the meeting hall had been much improved and the library accommodation increased. A standing Committee, entitled the Inventions Advisory Committee, had been formed to assist members, while another committee, entitled Works of National Importance Committee, had been established to consider proposals for works of national importance which could be submitted to the Government for consideration with the view of lessening unemployment. The report contains short reviews of the work done by the various research committees, the awards for papers and the results of the examinations for National Certificates and Diplomas in Mechanical Engineering. For these examinations there were 2,989 candidates in England and Wales, 226 in Scotland and 37 in Northern Ireland; a greater number than in any previous year. Twenty National Diplomas (Air) in Mechanical Engineering were awarded jointly by the Institution, the Board of Education and the Air Ministry.

\section{Streets and Pavements in London}

IN a paper read to the Newcomen Society on February 21, an interesting sketch was given of the history of the streets and pavements of London. In only two periods in its long history has London been efficiently paved and drained: in the days of 
the Romans and during the last hundred years. How well the Romans worked can be seen from the remains of causeways and sewers now and again brought to light during excavations in the City. With the departure of the Romans went the art of road-making, and for century after century the citizens accepted with extraordinary complacency conditions which would not be tolerated in any eity to-day. As a rule, the roads were unfit for wheeled traffic, the sidewalks were of gravel and dirt, the rain spouts projected over the pavements and such sewers as there were were connected ineffectively with gutters full of holes. Complaints were made over and over again, and though surveyors and paviors were appointed, things were seldom satisfactory. Even in the days of Wren and Newton, Ludgate Hill and Fleet Street drained into the mudfilled Fleet River, which had long ceased to be navigable and had become a nuisance. Westminster was every bit as bad as London, and in 1742 Lord Tyrconnel in the House of Lords said: "The filth of some parts of Westminster and the inequality and ruggedness of others, cannot but in the eyes of the foreigners disgrace our nation, and incline them to imagine us a people, not only without delicacy, but without government, a herd of barbarians, or a colony of hottentots". Improvements were effected from time to time, it is true, but it was only during last century that real progress was made.

\section{Archæological Exhibitions at the British Museum}

AT the recent annual meeting of the subscribers to the British School of Archæology in Athens, reference was made in the usual review of the School's work to the votive house, or temple, models which had been discovered in the course of the excavation of the Heræum at Perachora, near Corinth. From incomplete fragments a complete model has been reconstructed, which is now on view in the British Museum. The model is about a foot in height, and gives for the first time an idea in detail of the character of the house in the Egean during the Geometric period. The models are dated at about the middle of the eighth century B.c. The most striking feature of the construction is the apse, which Sir Arthur Evans has suggested may have arisen from the earliest form of building, in which the back wall was formed by hollowing out a cliffface. The door of the building has antæ with columns, and above it are three small windows.

ON March 7 an exhibition will open of the finds of the joint expedition of the British Museum and the British School of Archæology in Iraq under the leadership of Mr. M. E. I. Mallowan, at Arpachiyah, near Nineveh, in northern Iraq, during the season 1932-33. This material should have been on view last summer, but its dispatch from Iraq was delayed by action of the Government in settling the allocation of the material found by the expedition. The finds now shown will illustrate the cultures of the ten successive prehistoric settlements discovered at Arpachiyah. This sequence, in which the occurrence and development of the painted pottery can be followed from the earliest settlement, and the evidence of early relations with prehistoric India, Baluchistan, southern Mesopotamia and Crete, make Arpachiyah one of the most important sites known for the early prehistory of Iraq. Unfortunately, partly owing to lack of funds, excavations have been suspended.

\section{Recent Acquisitions at the Natural History Museum}

By the will of the late Lieut.-Col. C. G. Nurse, the Trustees of the British Museum (Natural History) have received a bequest of 3,000 Indian insects mostly obtained at Quetta, Deesa and Jubbulpore, where Col. Nurse served with the Indian Army. Col. Nurse was one of the small band of naturalists among military officers who devoted their leisure to the study of entomology, and was an enthusiastic collector of Hymenoptera, forming a large and valuable collection which he presented to the Museum a few years ago. The present bequest comprises the remainder of his Indian insects and includes about 1,450 Diptera (two winged flies), 1,300 butterflies, 130 dragon-flies and some others; of these the most valuable are the Diptera. The collection is especially rich in species of the family Bombyliidæ, most of which are parasitic in the larval state on bees or wasps. Col. Nurse discovered and described fourteen species of this family which were new to science, and types of these are in the collection, as well as specimens of a number of other flies which were not previously represented in the Museum. Some interesting butterflies and other insects from Aden are included.

The Department of Botany of the Museum has been presented with sixty-three bundles of plants by the Hancock Museum, Newcastle-upon-Tyne. These plants were presumably presented to the Newcastle Museum by William Robertson, who bought them at the sale in 1842 of A. B. Lambert's herbarium, which was one of the largest ever in private hands. The specimens are of historical interest as they presumably include the remainder of the herbarium of $\mathrm{P}$. S. Pallas, a Russian botanist who died in 1811. Pallas's plants were acquired by Lambert, who picked out one set for himself and one for Sir Joseph Banks. Banks's set went to the Museum in 1827 , and Robert Brown purchased Lambert's own set at the sale. Judging from the specimens so far examined, the present acquisition represents the remainder of the herbarium. Much will probably be duplicate material but a good deal of information can be obtained from the original wrappers in which the plants still are. Further, it is probable that some plants figured by Pallas, which have been missing, will be brought to light. The bundles also contain about 500 plants collected by the Rev. E. D. Clarke, who visited Pallas in the Crimea in 1800. The plants were named by Pallas. Among the purchases are 800 flowering plants from Spain and Morocco (Sennen), 1,500 from North America (Marcus E. Jones) and 900 from Eastern Greece, Egean Islands, etc. (K. H. Rechinger). 